http://jmscr.igmpublication.org/home/ ISSN (e)-2347-176x ISSN (p) 2455-0450

crossref DOI: https://dx.doi.org/10.18535/jmscr/v8i1.102

Journal Of Medical Science And Clinical Research

\title{
Triple Assessment in Evaluation of Breast Lump
}

\author{
Authors \\ Dr Saispandana.D ${ }^{1^{*}}$, Dr C. Sree Harsha ${ }^{2}$, Dr S.V. Satyanarayana Rao ${ }^{3}$ \\ ${ }^{1}$ Postgraduate, Department of General Surgery, Gems, \\ ${ }^{2}$ Sr.Resident, Department of General Surgery, Govt Medical College Anantapur, \\ ${ }^{3}$ Professor, Department of General Surgery, GEMS. \\ *Corresponding Author \\ Dr Saispandana.D
}

\begin{abstract}
Background: The breast triple assessment is a hospital-based assessment clinic that allows for the early and rapid detection of breast cancer. The triple-assessment aims to provide a quick and simple outpatient approach to diagnosis and allow for the early intervention in the treatment of breast cancer. At each stage of the triple assessment, the suspicion for malignancy is graded to create an overall risk index. The key here is to establish whether this is likely a benign lesion or whether the patient should go onto have more definitive biopsy and further intervention.
\end{abstract}

Materials and Methods: A total of 100 patients were involved in prospective, randomized observational study in department of general surgery admitted with breast lumps in GREAT EASTERN MEDICAL SCHOOL AND HOSPITAL. Patients belonging to10 and 70 years presenting with breast lump are included in the study.

Results: in the present study we found 94\% of cases i.e. 94 cases give concordant results while results of 6 patients shows non-concordance either benign or malignant. But none of the results shows the malignant one as benign.

Conclusion: The clinical examination has low sensitivity and thus should always be corroborated with other modalities of investigation. FNAC gives fairly good results in terms of sensitivity and specificity. USG and Mammography have given consistent and acceptable results. When three modalities of investigation viz. physical examination, imaging, and FNAC is combined the sensitivity, specificity and accuracy increases more than any of individual tests.

\section{Introduction}

Breast cancer is the $2^{\mathrm{ND}}$ most common malignancy in women worldwide, however, benign lesions of the breast are far more frequent than malignant ones. With the use breast imaging and the extensive use of needle biopsies, the diagnosis of a benign breast disease can be accomplished without surgery. It is to distinguish between in situ and invasive breast cancer so most appropriate treatment modality can be established. The triple test for breast diseases involve,

1. Clinical assessment

2.Imaging modality- Mammography

3. Fine needle aspiration biopsy/cytology

In modified triple test ultra-sonogram is used instead of mammography.

When combined in the triple assessment, a definitive diagnosis can be made when the 
diagnoses concur, suggesting that the triple assessment has a high sensitivity, specificity. Mammography is preferred method for breast cancer screening. But when mammography reveals a non-palpable breast lesion further imaging studies are often required to more precisely identifying the characteristics and location of the mass.

\section{Aim of study}

Aims: The study role of the triple assessment test in making a pre-procedural diagnosis of palpable breast lumps.

\section{Methodology}

\section{Source of Data}

The material of the study comprised of 100 patients admitted with breast lumps admitted GREAT EASTERN MEDICAL SCHOOL AND HOSPITAL during period of December 2018 to September 2019.

\section{Method of Collection of Data}

A Proforma drafted for the study of all patients with breast complaints, like lump, nipple discharge, Evaluation will be done by history, clinical

examination, mammography, Ultrasonogram, FNAC and HPE.

Sample size: 100 patients

Sampling method: Simple random sampling Inclusion Criteria: Females between 10 and 70 years presenting with breast lump with or without associated symptoms.

Exclusion Criteria: Patients with Open biopsy and HPE performed prior to presentation to our hospital.

\section{Results}

\section{Age Distribution}

Out of 100 cases, 31(31\%) patients had malignancy and rest 69(69\%) patients had a benign lesion. All the patients were above the age of 15 years. The mean age if malignancy cases was $51+/-9.8$ (28-67 years).

The mean age of benign cases was $27.63+/-$ $8.25(10-60$ years). The distribution is tabulated here under:

Table: Age variables among malignant and benign cases

\begin{tabular}{|l|c|c|c|}
\hline & Total Patients & Malignant cases & Benign cases \\
\hline Mean & 34.88 & 51 & 27.63 \\
\hline Median & 32 & 53 & 26 \\
\hline Mode & 24 & 54 & 24 \\
\hline SD & 12.64 & 9.83 & 8.25 \\
\hline Min age & 10 & 28 & 10 \\
\hline Max age & 67 & 67 & 60 \\
\hline Total & 100 & 31 & 69 \\
\hline
\end{tabular}

2. Site of Breast Lump: Out of 100 patients, $4(4 \%)$ patients had lesions in both the breasts. All these were benign. 20(64\%) patients of malignant lesions were in the right breast. Similarly, benign lesions also had right sided predominance. Following chart and table summarise the laterality of lesions in the breast, and incidence of simultaneous bilateral lesions.

Table: incidence of bilateral lesions and distribution of lesion according to side

\begin{tabular}{|l|c|c|c|}
\hline \multirow{2}{*}{ breast lump side } & \multicolumn{2}{|c|}{ Histopathological diagnosis } & \multirow{2}{*}{ Total } \\
\cline { 2 - 3 } & benign & Malignant & $4(4 \%)$ \\
\hline both & $4(4.66 \%)$ & $0(0.00 \%)$ & $40(40 \%)$ \\
\hline Left & $29(43)$ & $11(36 \%)$ & $56(56 \%)$ \\
\hline right & $36(52)$ & $20(64 \%)$ & $100(100 \%)$ \\
\hline TOTAL & $69(100)$ & $31(100 \%)$ & \\
\hline
\end{tabular}


3. Quadrant Distribution: $46 \%$ of malignant lump was in the right upper outer quadrant compared to $38.3 \%$ of benign lump.

4. Distribution of Cases on Clinical Examination; After history and complete physical examination, provisional diagnosis of benign lesion was made in $75(75 \%)$ patients, and that of malignant lesions in $25(25 \%)$ patients

\begin{tabular}{|l|l|l|}
\hline Lesions & number of cases & Percentage \\
\hline Benign & 75 & $75 \%$ \\
\hline Malignant & 25 & $25 \%$ \\
\hline total & 100 & 100 \\
\hline
\end{tabular}

\section{Distribution of Cases According to} Ultrasound Scans: On ultrasound scan,70(70\%) lesions were diagnosed as benign compared to $30(30 \%)$ patients to have malignant features. In this calculation, suspicious lesions have been Converted And Statistically Treated As Malignancy

\begin{tabular}{|l|c|c|}
\hline $\begin{array}{l}\text { Lump Defined On Us } \\
\text { Scan }\end{array}$ & $\begin{array}{c}\text { Total Of } \\
\text { Cases }\end{array}$ & Percentage \\
\hline Benign & 70 & $70 \%$ \\
\hline Malignant & 30 & $30 \%$ \\
\hline Total & 100 & 100 \\
\hline
\end{tabular}

6. Distribution Of Cases According To Mammography: Of 33 Patients Who Underwent Mammographic Examination, 28(84.8\%) Patients Had Malignant Features.

Table: Distribution Of Cases According To Mammography

\begin{tabular}{|l|c|c|}
\hline Mammography & Total & Percentage \\
\hline Benign & 5 & 15.2 \\
\hline Malignant & 28 & 84.8 \\
\hline Total & 33 & 100 \\
\hline
\end{tabular}

\section{Distribution of Cases as per FNAC:}

FNAC resulted in 68(68\%) lesions to be classified as of benign nature and32 (32\%) as malignant or suspicious of malignancy. Following chart and table summarise these findings.

Table: distribution of cases in FNAC results

\begin{tabular}{|l|c|c|}
\hline FNAC & total & Percentage \\
\hline benign & 68 & 68 \\
\hline Malignant & 32 & 32 \\
\hline total & 100 & 100 \\
\hline
\end{tabular}

\section{Distribution of Cases as per FNAC:}

FNAC resulted in 68(68\%) lesions to be classified as of benign nature and $32(32 \%)$ as malignant or suspicious of malignancy. Following chart and table summarise these findings.

Table: distribution of cases in FNAC results

\begin{tabular}{|l|c|c|}
\hline FNAC & total & Percentage \\
\hline benign & 68 & 68 \\
\hline Malignant & 32 & 32 \\
\hline total & 100 & 100 \\
\hline
\end{tabular}

\section{Histopathological Diagnoses}

8. Benign Cases: Most common diagnoses patients in the benign group was fibroadenoma $31(45 \%)$ followed by fibrocystic disease/ changes, $24(35 \%)$ and fibro adenomatoid hyperplasia constituting $12(17 \%)$ patients. One patient each had juvenile fibroadenoma and phyllode's tumour.

Table: Different diagnoses of the breast lesions that were benign at histopathology

\begin{tabular}{|l|c|c|}
\hline \multicolumn{3}{|l|}{ Distribution of benign cases } \\
\hline histopathological diagnosis & number & Percentage \\
\hline FAH & 12 & 17 \\
\hline FCC/FCD & 24 & 35 \\
\hline Fibroadenoma & 31 & 45 \\
\hline JUVENILE & 1 & 1 \\
\hline PHYLLOIDES & 1 & 1 \\
\hline TOTAL & 69 & 100 \\
\hline
\end{tabular}

\section{Concordence in Physical Examination,} Imaging and FNAC

$94 \%$ of cases i.e. 94 cases give concordant results while results of 6 patients shows non-concordance either benign or malignant. But none of the results shows the malignant one as benign.

\section{Combined}

Diagnostic value of the combined tests (combination of clinical diagnosis, imaging and FNAC was calculated and shown in following table. 93.6\% cases showed concordant results i.e. either all benign or malignant. One case in the benign group turned out to be malignancy in histopathological examination. However, none of the cases diagnosed as malignancy turned out to be of benign nature the histopathological examination. Non concordant results were observed in 8 cases. 
The sensitivity was $96.29 \%$ whereas specificity and positive predictive value were $100 \%$ respectively. The overall accuracy of triple test was $98.9 \%$.

Table: Comprehensive table showing the combined sensitivity, specificity, negative predictive value, positive predictive value and accuracy of the tests.

\begin{tabular}{|l|c|c|c|c|c|c|c|c|}
\hline \multirow{3}{*}{ Triple test } & \multicolumn{2}{|c|}{ histopathology } & \multirow{3}{*}{} & sensitivity & specificity & PPV & NPV & Accuracy \\
\cline { 2 - 5 } \cline { 7 - 9 } & benign & malignant & total & TP/TP+F & TN/TN+F & & TN/TN+ & TP+TN/TP+TN+FP+ \\
benign & 67 & 1 & 68 & $\mathrm{~N}$ & $\mathrm{P}$ & TP/TP+FP & FN & FN \\
\hline malignant & 0 & 26 & 26 & $26 / 26+1$ & $67 / 67+0$ & $26 / 26+0$ & $67 / 67+1$ & $67+26 / 94$ \\
\hline total & 67 & 27 & 94 & 96.29 & 100 & 100 & 98.5 & 98.9 \\
\hline
\end{tabular}

\section{Discussion}

\section{Epidemiological Data}

Carcinoma of the breast Is the most common sitespecific cancer in women. Our study shows majority of patients had benign lump (69\%). Of 100 patients who selected for study after fulfilling inclusion criteria, all patients were regularly followed-up till completion of study. In the present study the mean age of malignant cases was $51+9.8(28-69$ years $)$. The mean age of benign cases was $27.63 \pm 8.25$ (10-60years). This finding is similar to some other studies reporting age ranging from 45-55 years.

All the lumps were found more commonly situated at the upper and outer quadrants of breast,
$68 \%$ of benign lumps and $74 \%$ of malignant ones, compatible to findings with other studies and also because of the anatomical organisation of breast volume, more than $3 / 5^{\text {th }}$ of the breast tissue lies in upper outer quadrant.

\section{Comparison of Triple test results with other studies}

The following table compares the present study with different 6 studies undertaken at different parts of world since 2005 in terms of sensitivity, specificity, PPV, NPV, and accuracy of the tests. The results are comparable in all aspects. The accuracy of tests when combined is $97 \%$.

Table: showing comparison of triple test with various studies

\begin{tabular}{|l|c|c|c|c|c|c|}
\hline AUTHOR & YEAR & SE & SP & PPV & NPV & ACCURACY \\
\hline Martelli G et al & 2005 & $95 \%$ & $\ldots \ldots \ldots$ & $100 \%$ & $\ldots \ldots$ & $\ldots \ldots$ \\
\hline Vetto J et al & 2008 & $100 \%$ & $57 \%$ & $74 \%$ & $100 \%$ & $100 \%$ \\
\hline Steinberg et al & 2008 & $95 \%$ & $100 \%$ & $\ldots \ldots \ldots$ & $\ldots \ldots$ & $\ldots \ldots$ \\
\hline Morris A et al & 2010 & $100 \%$ & $100 \%$ & $73.50 \%$ & $100 \%$ & $\ldots \ldots$ \\
\hline Ghimire Bikal et al & 2012 & $100 \%$ & $95.20 \%$ & $96.70 \%$ & $\ldots \ldots$ & $98 \%$ \\
\hline Jan masooda et al & 2014 & $100 \%$ & $99.30 \%$ & $93.30 \%$ & $100 \%$ & $\ldots \ldots$ \\
\hline present study & $\mathbf{2 0 1 7}$ & $\mathbf{9 6 . 7 0 \%}$ & $\mathbf{9 7 . 1 0 \%}$ & $\mathbf{9 3 . 7 5 \%}$ & $\mathbf{9 8 . 5 0 \%}$ & $\mathbf{9 7 \%}$ \\
\hline
\end{tabular}

\section{Conclusion}

The clinical examination has low sensitivity and thus should always be corroborated with other modalities of investigation. FNAC gives fairly good results in terms of sensitivity and specificity. USG and Mammography have given consistent and acceptable results. When three modalities of investigation viz. physical examination, imaging, and FNAC is combined the sensitivity, specificity and accuracy increases more than any of individual tests. When all three diagnostic modalities are agreement for a diagnosis of malignant disease, the combination of clinical examination, FNAC, USG has excellent concordance with the result of excisional biopsy, and in this situation definitive treatment may be carried out. If all three modalities are in a agreement with diagnosis of benign disease, a period of close observation with repetition of FNAC may be safely entertained. 


\section{References}

1. Lester SC. The breast. In: Kumar V, Abbas AK, Aster JC, Fausto N, editors. Robins and Cotran Pathologic Basis of Disease. 8th ed. Vol. 23. Philadelphia: Saunders an Imprint of Elsevier; 2010. pp. 1068-9.

2. Bannister LH, Berry MM, Collins P, et al, editors. Gray's Anatomy. 38th ed. New York: Churchill Livingstone, 1995:417-24.

3. Stavros AT, Thickman D, Rapp CL, Dennis MA, Parker SH, Sisney GA. Solid breast nodules: use of sonography to distinguish benign and malignant lesions. Radiology. 1995;196:123-34.

4. Meyberg-Solomayer GC, Kraemer B, Bergmann A, Kraemer E, Krainick U, Wallwiener D, Solomayer EF. Does 3-D sonography bring any advantage to noninvasive breast diagnostics? Ultrasound Med Biol. 2004;30:583-9

5. Reinikainen HT, Rissanen TJ, Pilippo UK, Paivansalo MJ; Contribution of ultrasonography and fine-needle aspiration cytology to the differential diagnosis of palpable solid breast lesions. Acta Radio 1999 Jul;40(4):383-9

6. Ashley S, Royale JT, Rubin CM; Clinical, radiological and cytological diagnosis of breast cancer in young women; $\mathrm{Br} \mathrm{J}$ Surg, 1989;76(8):835-7

7. Ghazala Malik, Fareesa Waqar, Ghulam Qadir Buledi; Sonomamography for evaluation of solid breast masses in young patients. J Ayub med coll Abbottabad, 2006;18(2):34-6

8. Philip J Drew, Lindsay W Turnbull, Sumohan Chatterjee, John Read, Peter J Carleton, et al. Prospective Comparison of Standard Triple Assessment and Dynamic Magnetic Resonance Imaging of the Breast for the Evaluation of Symptomatic Breast Lesions. Annals of Surgery 230(5):680

9. Tabbara SO, Frost AR, Stoler MH, Sneige $\mathrm{N}$, Sidawy MK. Changing trends in breast fine-needle aspiration: Results of the
Papanicolaou Society of Cytopathology Survey. Diagn Cytopathol. 2000;22:12630.

10. Kim A, Lee J, Choi JS, Won NH, Koo BH. Fine needle aspiration cytology of the breast. Experience at an outpatient breast clinic. Acta Cytol. 2000;44:361-7.

11. Morris A, Pommier RF, Schmidt WA, Shih RL, Alexander PW, Vetto JT. Accurate evaluation of palpable breast masses by the triple test score. Arch Surg. 1998;133:930-4.

12. Park IA, Ham EK. Fine needle aspiration cytology of palpable breast lesions. Histologic subtype in false negative cases. Acta Cytol. 1997;41:1131-8

13. Rubin M, Horiuchi K, Joy N, Haun W, Read R, Ratzer E, et al. Use of fine needle aspiration for solid breast lesions is accurate and cost-effective. Am J Surg. 1997;174:694-6.

14. Vetto J, Pommier R, Schmidt W, Wachtel M, DuBois P, Jones M, et al. Use of the "triple test" for palpable breast lesions yields high diagnostic accuracy and cost savings. Am J Surg. 1995;169:519-22. 